\title{
Latest thinking on attaching a financial value to marketing strategy: Through brands to valuing relationships
}

\author{
RECEIVED (IN REVISED FORM): 22 JANUARY, 200I \\ Keith Ward ${ }^{*}$ and Lynette Ryals \\ "Cranfield School of Management, Cranfield University, Cranfield, Bedford MK43 OAAL; \\ Tel: +44 (0)234 75। I22; Fax: +44 (0)234 75। 806; \\ e-mail: krward@btinternet.com
}

\begin{abstract}
Keith Ward is visiting professor of financial

strategy at

Cranfield School

of Management.

He was previously

head of the

Finance and

Accounting group

at Cranfield.

Lynette Ryals is

a lecturer in

Marketing at

Cranfield School

of Management

and Director of

the Executive

MBA Programme.

She was previously

a City trader and

is a Fellow of

UKSIP, the society

for investment

professionals.
\end{abstract}

\section{AbSTRACT}

The requirement for marketing expenditures to be financially justified is now very common, and increasingly this financial evaluation is done in terms of how the marketing strategy contributes to shareholder value. For many leading companies this led to an initial focus on financially evaluating and managing brands. Now the emphasis is turning towards valuing customer relationships, as marketing strategies become increasingly customer based.

This paper examines the latest thinking on applying financial evaluation and control techniques to these types of marketing strategies. The need for a more sophisticated approach to the financial valuation of customer relationship-based marketing strategies is discussed, involving conditional probabilities, simulations and possibly even real options. Many other implications of a more strategic financial approach in this area are also raised.

\section{INTRODUCTION}

The most common overriding mission or goal of modern commercial cor- porations is the creation of shareholder value. This financially focused objective has to be achieved through the organisation's more market-oriented goals and objectives, but it can also constrain these product, brand and customer strategies. Indeed a number of respected commentators have recently suggested that the key objective of marketing is its contribution to the creation of shareholder value. ${ }^{1-4}$

This places considerable pressure on the interface between marketing and finance, because traditional financial evaluation and control approaches to marketing activities have only gone as far as product or customer contributions, not even true profit levels. Shareholder value is only created after the company's required rate of return on its capital base has been allowed for. Further, the creation of value often requires a long-term focus rather than the annual time frame which is normally used for projecting profits in the financial planning and control process. This is because future value can obviously be created from 
current marketing expenditure, and these value-creating investments need to be evaluated and controlled appropriately. Traditionally all marketing expenditure has been expensed in the period in which it takes place and yet, in most organisations today, marketing assets represent the major source of current and future shareholder value creation.

Consequently, marketing finance is an area currently undergoing dramatic development in many companies. Unfortunately, while the marketing evaluation ideas and processes are now quite well developed, the financial processes often lag behind. Too often, finance managers are simply trying to apply their normal investment appraisal techniques (primarily based on discounted cash flows) to the wide range of strategic marketing investments being proposed and made by their marketing colleagues. As discussed in this paper, the challenge lies not in developing new techniques but in finding more relevant and tailored ways of applying them to different marketing strategies.

The essential role for financial evaluation and control as part of the marketing planning process is now accepted by leading companies and, in some cases, the marketing finance manager works closely with the marketing research team to help develop a fact-based marketing strategy. For many companies, particularly in the fast moving consumer goods (fmcg) industries, this process started by measuring and managing brand values but the latest area of focus is on customer relationships.

This is a further development of a trend to discuss the customer relationship as an asset to be proactively managed. This concept regards sustainable business success as requiring the total value created by the company to be shared between customers and shareholders (together with other key stakeholders). Thus customers (like brands) may absorb substantial investments before they start to generate a financial return but, if managed properly, they can continue to produce high value adding returns for many years. This emphasises the relationship with the customer as a fundamental driver of shareholder value creation. ${ }^{5-8}$ This financial evaluation process is reinforced by the relationship marketing literature which emphasises the link between customer retention and increased financial returns. ${ }^{9-11}$

\section{BRAND EVALUATION}

Brand values leapt to prominence in the media during the late 1980s as a consequence of some high profile takeovers (eg Rank Hovis McDougall and Grand Metropolitan's acquisition of Smirnoff Vodka) and the resulting appearance of some very substantial brand values on company balance sheets. ${ }^{12}$ The marketing strategy challenge revolves less around establishing a single particular brand value and more about how to manage the brand so as to maximise the economic value generated from it during its value 
enhancing life (ie brand evaluation rather than valuation). The fundamental financial issues remain the same, however; forecasting the future cash flows which are expected to be generated from the brand and then discounting these cash flows back to their present values at an appropriately risk adjusted discount rate.

Clearly the resulting present 'value' of the brand needs to be treated rather circumspectly, but deriving such a 'value' can dramatically assist in evaluating the marketing strategy of any brand-based business. A key issue in strategic planning is the allocation of financial resources and this is critical to the success of any marketing strategy. Should more marketing money be spent in developing an exciting growing brand still further, relocated to launching a new brand, or put into maintenance support for a large but mature brand which is coming under intense competitive pressure.

The long-term financial impact of these alternatives can best be assessed by comparing the relative changes in each of the brand evaluations of spending and not spending behind the brand; the net changes in present value give a much more shareholder value oriented perspective than can be achieved by comparing the relative impacts on this year's profit.

There are a number of stages involved in successfully developing, and then maintaining, a brand as a value-enhancing asset. Marketing has developed very specific effectiveness measures for each element in this brand-building process (eg for a repeat purchase consumer brand awareness creation, propensity to purchase, ability to purchase such as distribution trial rates, repeat purchase incidence and, ultimately, levels of regular usage). The financial evaluation and control challenge is to develop financial models which incorporate those non-financial effectiveness measures into a comprehensive brand evaluation process.

Several companies are now using such models as key elements in attaching a financial value to their marketing strategies (eg Diageo and British American Tobacco). Further refinement of such models include brand launch evaluations, which are carried out prior to the full marketing launch of any new brand, and are based on test market data and previous experience of similar launches. Interestingly these companies, where publicly quoted on stock markets, are giving increasing amounts of detail to their shareholders and the stock market analysts on their marketing expenditures and how they are financially evaluated and controlled.

\section{DEVELOPMENT VERSUS MAINTENANCE EXPENDITURE}

Most companies, however, including those leading edge fmcg businesses, still traditionally classify their marketing expenditure. The distinction is often made between 'above the line' and 'below the line' expenditure, whereas what is important is the purpose of the expenditure. If the objective of 
the expenditure is to improve the attributes of a brand (eg increase the unprompted awareness), then this development activity may not produce a financial return in the current financial year. The investment in the brand, however, may add substantial value to the long-term brand evaluation model, and hence should be carried out.

Unfortunately, most companies still use annual profits or short-term cash flows as their primary method of assessing financial performance. Hence, if this year's profit target is under pressure, economically valid development marketing activity may be curtailed as the deferral of expenditure will improve the perceived short-term financial performance; albeit at the expense of the long-term strength of the business' critical assets.

This would not be true if companies did actually properly evaluate the value created by their development marketing expenditure. If this were done, the development expenditure should result in an increased brand asset value, which would more than offset the apparent reduction in the profit caused by writing off the marketing expenditure this year. Further that change would also more accurately reflect the impact of the ultimate short-termist marketing tactic; ie to cut back on all marketing expenditure if current profits are really threatened.

Reducing even maintenance marketing activity (ie that support required to keep existing brand attributes at their current level) will, under tradi- tional accounting treatments, enhance short-term profitability, even though it places at risk the existing major assets of the organisation. If, however, this reduction was properly reflected (eg on the balance sheet) by reducing the brand value appropriately, the true long-term financial impact of this shortterm change in marketing philosophy would be much more visible.

\section{RELATIONSHIP MARKETING}

Relationship marketing has helped to shift the marketing perspective from product or competitor driven marketing to customer focus. ${ }^{13,14}$ Relationship marketers view the customer relationship, rather than the product transaction, as a competitive differentiator and a key driver of long-term profitability. Traditionally, marketing has tended to focus on sales growth and market share rather than evaluating the impact of marketing decisions on shareholder value creation. ${ }^{15}$ In a relationship marketing world, marketing strategy shifts towards investment in customer retention rather than customer acquisition. The priority should be investment in retaining the most valuable customers. It is important that marketers understand which customers will repay the effort and investment required, as over-investment in unattractive customers will destroy shareholder value. So, customers create shareholder value for a company. In order to attract customers, the company must, in its turn, create value for those customers. To 
retain customers, it must continue to create more customer value than the competition.

\section{CUSTOMER VALUE}

Customer value is the perceived benefit obtained by the customer less the price or other sacrifices of time, convenience etc that the customer makes to own the product or service. ${ }^{16-20}$ Where the perceived benefit derived by the customer is greater than the sacrifices made, customer value is created.

Customers' perception of value is based on more than specification, features, and price. ${ }^{21,22}$ Naumann ${ }^{23}$ suggests that value perceptions are formed over time, on the basis of:

- search attributes (expectations formed prior to purchase)

- experience attributes (experience during ownership)

- credence-based attributes (associated with the brand and the views of others).

Brands and other intangible marketing assets are difficult to value within traditional management accounting. ${ }^{24}$ They can, however, be an important component of the creation of customer value. Customers who do not perceive that they are getting value from a relationship are likely to defect. This makes it critical that marketers are able to identify profitable customers and target them with appropriate marketing strategies.

\section{MEASURING THE VALUE OF CUSTOMERS}

The literature demonstrates that relatively few companies have been assessing customer profitability or customer lifetime value ${ }^{25}$ although more than one study has indicated that customer profitability is thought by companies to be an increasingly important performance indicator. ${ }^{26}$ Several studies explore the connection between customer satisfaction, customer retention and corporate profitability, ${ }^{27,28}$ the so-called 'Service-Profit Chain'. ${ }^{29-30}$ The field of service quality and the economic worth of customers is surveyed by Zeithaml. ${ }^{31}$

Sophisticated tools now exist to assess the value to a company of individual customers. In particular, the development of data warehouses and data mining tools assist organisations in measuring the value of customers. Predictive modelling, for example, can be used to predict the remaining lifetime of the relationship with the customer and the likely future revenues and costs of that customer. Data mining can also improve the management of the customer relationship, as in the case of the insurance company which discovered that customers who were about to defect had characteristic behaviour patterns. It inserted a function onto its data warehouse to identify these behaviour patterns as they emerged and set up a new team to manage those customers who might otherwise have been lost. ${ }^{32}$

Examples like these demonstrate that techniques to assess individual 
customers do exist, supported by current technology. So, why is it that, as we have seen, most companies are not valuing their customer relationships? From a marketing perspective, a better understanding of both sides of the customer relationship (the value created for and by customers) has two applications. The first is tailoring products or services and thereby increasing customer value; the second is segmentation and targeting of more attractive customers, thereby increasing shareholder value. Previously, marketers have tended to talk about segmentation as though it is only about customer value and not about shareholder value. $U p$ to a certain point, customer value and shareholder value move in lockstep. Increasing customer value will increase shareholder value. Beyond that point, however, increasing customer value will actually destroy shareholder value. ${ }^{33}$ Marketers need to be able to identify where this point is, to make decisions about marketing strategies that will create shareholder value. This is why it is critically important for marketers to be able to value customer relationships.

\section{VALUING RELATIONSHIPS}

Companies who take the valuation of their customer relationships seriously use net present value (NPV) calculations, identifying the stream of customer revenues and costs over the relationship lifetime and applying a discount rate to calculate the present value of the relationship.

Relationship marketing suggests, however, that profitability - even lifetime value - does not necessarily reflect the total value of the customer to the company. There can be value in a customer relationship over and above the economic value of the profit generated by the customer. ${ }^{34,35}$ In fact, long-term customer relationships do pay off for suppliers but it may be these relationship benefits that are largely responsible. ${ }^{36}$

Relationship benefits seem to be of four types. Referrals (word of mouth) and referencability reduce the cost of acquiring other customers; product innovation and learning from customers benefit the entire firm, perhaps by reducing overall costs or by suggesting innovations to add value.

Word-of-mouth referrals are highly valued by potential purchasers ${ }^{37}$ and an investment in customer relationships can pay off with a stream of referrals over a period of time, underlining the need to treat customers as assets. ${ }^{38,39}$ The reverse also applies, negative word of mouth can be extremely costly. ${ }^{40}$ Referencability, the possession of flagship accounts, can be very beneficial. ${ }^{41}$ Product innovation ideas often come from customers ${ }^{42}$ and learning from customers can reduce costs and risks for suppliers. ${ }^{43}$

The importance of these relationship effects is that they may explain why companies can create value for shareholders by dealing with certain customers, even if these customers do not themselves appear profitable even 
in accounting terms, let alone on a shareholder value basis. Jenkinson ${ }^{44}$ even suggests that revenue from referrals should be included in the lifetime value calculation of individual customers.

Relationship benefits are, however, difficult to value. Sometimes, this is because marketers simply do not collect information about the value of relationship benefits. They do not know what proportion of their customers come to them through word of mouth, for example, or whether these tend to be high-value or low-value customers. Even where this information exists, relationship benefits are subject to a high degree of uncertainty. They are often contingent upon the strength of the relationship. Customers may only be happy to make recommendations when their relationship is particularly good, for example; if their last service encounter was poor, a previously enthusiastic advocate may become reluctant to recommend or, worse, may generate negative word of mouth.

Because of the contingent nature of relationship benefits, they may have to be valued using slightly different techniques from a standard NPV approach. Three techniques are particularly useful: conditional probability, simulation, and real options. Of these, conditional probability is the most familiar and straightforward to apply and is therefore described in some detail. Simulations and real options are more sophisticated techniques borrowed from the fields of statistics and financial modelling, and their application to valuing customer relationships will only be briefly described. Real options are particularly fascinating and there is some evidence to suggest that options thinking explains some marketing decisions that key account managers make.

\section{CONDITIONAL PROBABILITY}

Conditional probability is a way of thinking about uncertain future events where the probability of a distant future event is conditional on a nearer future event which is itself uncertain. In other words, conditional probabilities are future probabilities conditional on specific outcomes in earlier years. $^{45}$

For example, a key account team might forecast referrals from their customer worth either $\mathcal{E} 3,000$ or $\mathcal{f}, 000$. The lower figure they think is more likely, so they assign probabilities of 70 per cent and 30 per cent respectively. These Year 1 figures are the initial probabilities.

If $f 3,000$ worth of referrals is the most likely result in Year 1 , it is a sign that the relationship is not going as well as the key account team would hope. They therefore predict that, in this case, referrals in year 2 would be either $\mathcal{E}^{3}, 000$ (with probability 10 per cent), $£ 2,000$ (with probability 50 per cent) or $£ 1,000$ (with probability 40 per cent). If, however, the Year 1 out-turn is $£ 5,000$, Year 2 will probably also result in more referrals, as shown in Figure 1. 
Figure 1: Expected cash flows from referrals and conditional probabilities

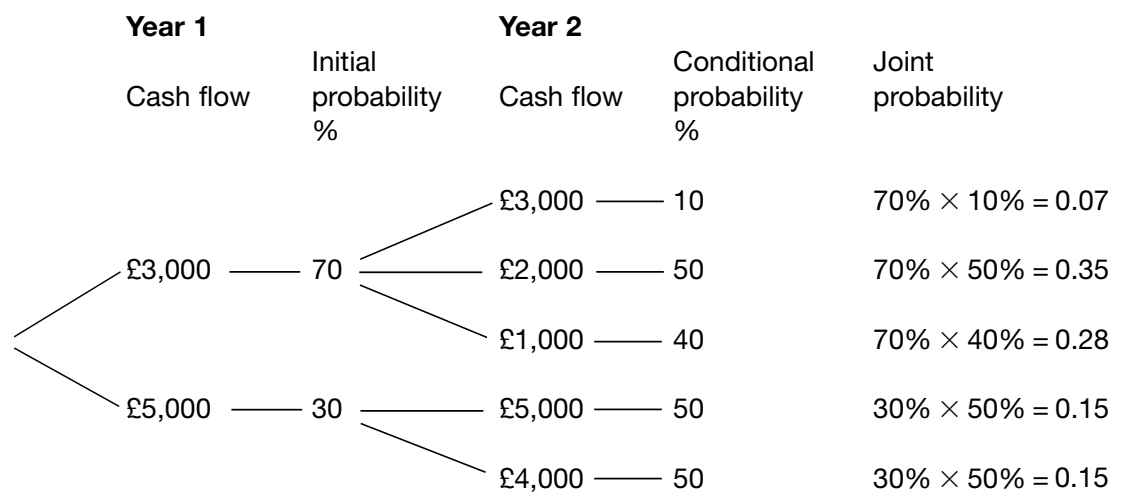

The expected net cash flow for Year 2 discounted at 10 per cent, ${ }^{46}$ were $\{3,000$ to be earned in Year 1, is therefore as shown in Table 1.

Conditional probability trees are constructed from forecasts of the amount, timing and probability of future cash flows. They are a good way to summarise cash flow consequences of decisions. ${ }^{47}$ They are an accepted valuation tool for management but suffer from certain limitations. For example, conditional probability trees are limited in the numbers of paths that they can handle before the tree becomes unacceptably complex. Moreover, the forecasts that managers are required to make in order to construct the tree are difficult probability forecasting, in particular, is difficult. A third disadvantage is that option values are not captured by conditional probability trees, which can mean that the trees understate the value of certain decisions.

\section{SIMULATION MODELS}

A simulation is a more sophisticated valuation method than conditional probability. By contrast to conditional probability trees, simulation models look at thousands of possible paths. For example, Monte Carlo simulations use random numbers to make simultaneous changes in numerous variables. Thousands of calculations allow Monte Carlo to simulate results based on real-world situations. ${ }^{48}$

Simulations make probability forecasting slightly easier. So long as the researcher identifies the probability distribution $^{49}$ implied in managers' responses, data collection is simplified.

The results from a simulation can also be used in the valuation of real options. ${ }^{50}$

\section{REAL OPTIONS}

Real options deal with situations in which investment decisions can be 


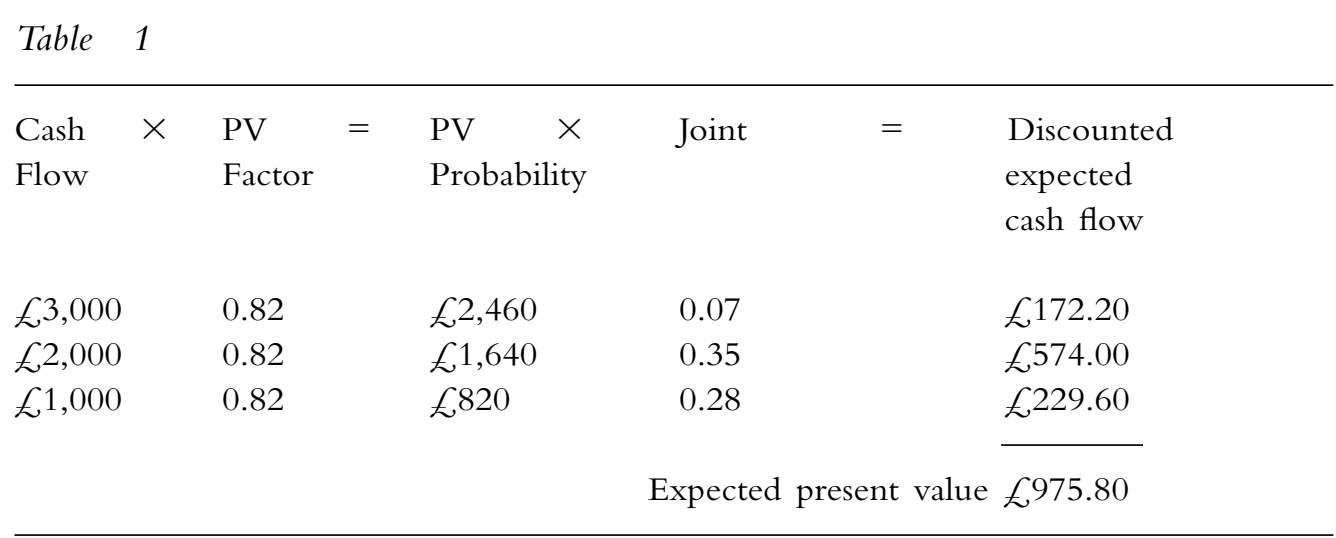

deferred. Deferral has value not just because an organisation can earn interest on the capital it retains, but also because deferring a decision until the business situation clarifies reduces the uncertainty surrounding that decision ${ }^{51}$ and increases flexibility. ${ }^{52}$

Where the investment cannot be deferred, the real option value and the NPV of a projected investment are identical. ${ }^{53}$

Real options is a technique that has been used in a number of areas, particularly in the evaluation of large, uncertain projects in the oil and pharmaceutical industries. To apply real options to valuing customer relationships, a marketer would need to evaluate the five factors that determine the value of a real option. These are:

- the present value of expected cashflows from that customer or customer segment

- investment costs in the customer relationship such as investments in tools and machinery, facilities, training etc.

- time until the opportunity disappears, after which the option to invest is no longer available. The opportunity might be quite shortlived, even in a long-term customer relationship. For example, a customer might offer an opportunity to invest in a joint project that requires a relatively rapid response

- uncertainty of expected cashflows. This can be measured as the standard deviation of the projected cashflows from that customer relationship

- risk-free interest rate. This is usually taken to be the return on a long gilt.

Real options cover a wider range of possibilities than decision trees and have the advantage that they incorporate a risk-adjusted element. The risk of an option changes as time and the present value of expected future cash flows change. Real option values 
are therefore dynamic in a way that simulations are not. ${ }^{54}$

Real options are, however, less commonly used and so less familiar to managers than decision trees. They are useful to value investments under uncertainty, but only where the opportunity to defer exists. If it is not possible to defer the investment, no option exists. Moreover, the uncertainty of cashflows from the customer relationship can be difficult to calculate, although it can be done either by educated guesswork, by using historical data on returns, or by computer simulation of future cash flows and the probability distribution using techniques such as a Monte Carlo simulation.

There is some evidence that real options thinking underlies some customer strategies adopted by marketers. If so, real options could be a valuable tool for marketers to value relationship benefits. The evidence for options thinking comes from some interviews recently conducted by one of the authors with a team of key account managers in a major international business-to-business insurer. When asked why they continued to do business with apparently unprofitable accounts, the managers said:

'You might renew it because it is high profile in the industry and it will get round the market' (reference/referral)

'We do it for the relationship. We do it because there might be other opportunities, like [new product]' (product innovation)

'Also, you have got the argument that, if you do just write it off, you have never got the opportunity to get anything back on it'. (uncertainty)

\section{DISCUSSION AND IMPLICATIONS}

As these examples illustrate, the importance of valuing customer relationships is well understood. A report by the Economist Intelligence Unit ${ }^{55}$ showed that customer profitability was expected to be the second most important measure of business performance by 2002 .

The authors would argue that marketing ideas about the value of customer relationships should go far beyond traditional customer profitability analysis. The latest thinking in valuing relationships with customers is that the relationship itself may have value over and above the value captured by customer profitability analysis, even NPV analysis. Some examples of relationship benefits include reference, referrals, learning and product innovation. The techniques to evaluate these relationship benefits may go beyond NPV analysis and incorporate conditional probability, simulations, and real options; and there is some evidence for options-type thinking among customer account managers.

Their argument is that relationship marketing is about creating and captur- 
ing relative value. The implications of this argument are that companies cannot maximise their shareholder value unless they are able to identify and target their most profitable customers. Companies not doing this run the risk of losing their most profitable customers to competitors who can identify and target them more accurately. The techniques described above are relatively new but proven analysis techniques which are particularly useful in valuing uncertain investments such as investments in customer relationships. The paper outlined briefly the way in which these techniques can be applied to the valuation of customer relationships. It has also been shown that most organisations are not in fact applying even the basics of customer profitability analysis and the authors have speculated as to why this appears to be the case. How companies can implement projects to value relationship benefits will now be briefly discussed.

The objective of implementing customer valuation is to value the relationship with that customer or group of customers sufficiently well to drive performance measurement and marketing strategies. It is suggested that the most effective project approach uses action research, in which a team of managers (with or without outside help) progressively implements the valuation of customers using frequent iterations and reflection. The reflection helps the team to learn from the project; it also assists them in making the crucial decision about when to stop: in other words, when the valuation is sufficiently accurate for marketing purposes. This will be well before the point at which the valuation is strictly accurate, but it is the most efficient place to stop the project.

The final discussion points concern the impact of a better understanding of the value of a customer relationship on marketing strategies. When strategies are driven, not just by traditional key accounts or segments, but also by profitability, then organisations will start to ask themselves about the payback on certain services before offering them to customers and increasingly to differentiate customers or segments by service levels. Part of the customer strategy has to be a decision about the share of value created from the relationship that a company wishes to capture. ${ }^{56}$ This is likely to have an impact for example, on channel strategies with certain customers encouraged to use lower-cost channels; and promotions may be more closely targeted and seen as a means of rewarding loyal customers rather than attracting new, low-loyalty ones.

The authors believe that the implications of understanding the value of customer relationships will also have organisational implications. Customer relationships are often maintained through boundary-spanning processes such as customer relationship management (CRM), and this will raise issues about how to incentivise people who contribute to a cross-boundary process. 
It seems likely that internal measurement and employee incentives will change from customer acquisition and volume-based metrics to customer value and retention metrics.

This paper has presented the latest thinking on attaching a financial value to marketing strategy. Further work is needed to demonstrate how knowing more about the value of customer relationships influences marketing strategies; and how marketing strategies based on the value of customer relationships impact on shareholder value.

\section{REFERENCES}

1 Doyle, P. (2000) 'Valuing marketing's contribution', European Management Journal, Vol. 18, No. 3, pp. 233-245.

2 Varadarajan, P. R. and Jayachandran, S. (1999) 'Marketing strategy: An assessment of the state of the field and outlook', Journal of the Academy of Marketing Science, Vol. 27, No. 2, pp. 120-143.

3 Srivastava, R. K., Shervani, T. A. and Fahey, L. (1998) 'Market-based assets and shareholder value: A framework for analysis', Journal of Marketing, Vol. 62, No. 1, pp. 2-18.

4 Srivastava, R. K., Shervani, T. A. and Fahey, L. (1999) 'Marketing, business processes, and shareholder value: An organizationally embedded view of marketing activities and the discipline of marketing', Journal of Marketing, Vol, 63, (Special Edition), pp. 168-179.

5 Grant, A. W. H. and Schlesinger, L.
A. (1995) 'Realise your customers' full profit potential', Harvard Business Review, Vol. 75, No. 5, p. 14.

6 Schultz, D. E. (1993) 'Marketing from the outside in', Journal of Business Strategy, Vol. 14, No. 4, pp. 25-29.

7 Axson, D. A. J. (1992) 'A return to managing customer relationships', International Journal of Bank Marketing, Vol. 10, No. 1, pp. 30-35.

8 Webster Jnr, F. E. (1992) 'The changing role of marketing in the corporation', Journal of Marketing, Vol. 56, No. 4, pp. $1-16$.

9 Christopher, M., Payne, A. and Ballantyne, D. (1991) 'Relationship marketing', Butterworth Heinemann, Oxford.

10 Reichheld, F. F. (1996) 'The loyalty effect', Harvard Business School Press.

11 Zeithaml, V. A. (2000) 'Service quality, profitability, and the economic worth of customers: What we know and what we need to learn', Journal of the Academy of Marketing Science, Vol. 28, No. 1, pp. 67-85.

12 Murphy, J. (ed.) (1989) 'Brand valuation - Establishing a true and fair view', Hutchinson, London, England.

13 Brodie, R. J., Coviello, N. E., Brookes, R. W. and Little, V. (1997) 'Towards a paradigm shift in marketing? An examination of current marketing practices', Journal of Marketing Management, Vol. 13, No. 5, pp. 383-406.

14 Webster Jnr, (1992) op. cit.

15 Srivastava, Shervani, and Fahey (1998) op cit.

16 Anton, J. (1996) 'Customer relationship management: Making hard deci- 
sions with soft numbers', Prentice-Hall, New Jersey.

17 Naumann, E. (1995) 'Creating customer value', Thomson Executive, Cincinnati.

18 Morris, T. (1994) Customer relationship management', CMA Magazine, Vol. 68, No. 7, pp. 22-25.

19 Rust, R. T. and Oliver, R. L. (1994) 'Service quality: Insights and implications', in 'Service quality: New directions in theory and practice', Sage, California.

20 Slater, S. E. and Narver, J. C. (1992) 'Superior customer value and business performance: The strong evidence for a market-driven culture', Marketing Science Institute Report, pp. 92-125.

21 Knox, S. D. and Maklan, S. (1998) 'Competing on value', FT Pitman, London.

22 Wiersema, F. (1997) 'Customer intimacy’, HarperCollins, New York.

23 Naumann, E. (1995) 'Creating customer value', Thomson Executive, Cincinnati.

24 Guilding, C. and Pike, R. (1990) 'Intangible marketing assets: A managerial accounting perspective', Accounting and Business Research, Vol. 21, No. 18, pp. 41-49.

25 Clark, R. (1999) 'Learn to protect your valuables', Customer Loyalty Today, May, p. 9.

26 Economist Intelligence Unit (EIU) (1998) 'Managing customer relationships', report with Andersen Consulting.

27 Hallowell, R. (1996) 'The relationships of customer satisfaction, customer loyalty and profitability: An empirical study', International Journal of Service In- dustry Management, Vol. 7, No. 4, pp. 27-42

28 Reichheld (1996) op. cit.

29 Rucci, A. J., Kirn, S. P. and Quinn, R. T. (1998) The employee-customerprofit chain at Sears', Harvard Business Review, Jan-Feb, pp. 82-97.

30 Storbacka, K., Strandvik, T. and Gronroos, C. (1994) 'Managing customer relationships for profit - The dynamics of relationship quality', International Journal of Service Industry Management, Vol. 5, No. 5, pp. 21-38.

31 Zeithaml, V. A. (2000) 'Service quality, profitability, and the economic worth of customers: What we know and what we need to learn', Journal of the Academy of Marketing Science, Vol. 28, No. 1, 67-85.

32 Ryals, L. J. (2000) CRM at Wesleyan: Going the extra mile. Case study', Cranfield School of Management, Cranfield.

33 McTaggart, J. M., Kontes, P. W. and Mankins, M. C. (1994) 'The value imperative - Managing for superior shareholder returns', Free Press, London.

34 Wayland, R. E. and Cole, P. M. (1997) 'Customer connections', Harvard Business School Press.

35 Wilson, C. (1996) Profitable customers', Kogan Page, London.

36 Kalwani, M. U. and Narayandas, N. (1995) 'Long-term manufacturer-supplier relationships: Do they pay off for supplier firms?', Journal of Marketing, Vol. 59, No. 1, pp. 1-16.

37 Anton (1996) op. cit.

38 Page, M. and Pitt, L. (1994) 'Analysing and managing defections: The value of 
keeping customers', Henley Working Paper HWP 94/14.

39 Harris, R. B. (1993) Trust: A foundation for building business', Managers Magazine, Vol. 68, No. 6, pp. 14-17.

40 Morris (1994) op. cit.

41 Burnett, K. (1992) 'Strategic customer alliances: How to win, manage, and develop key account business in the 1990s', Pitman, London.

42 von Hippel, E. (1988) 'The sources of innovation', OUP, New York.

43 Womack, J. P., Jones, D. T. and Roos, D. (1990) 'The machine that changed the world', Rawson Associates, New York.

44 Jenkinson, A. (1995) 'Valuing your customers: From quality information to quality relationships', McGraw Hill, London.

45 Copeland, T. E. and Weston, J. F. (1988) 'Financial theory and corporate policy', Addison-Wesley, US, (3rd edition).

46 A 10 per cent discount rate is used purely for illustration purposes.

47 Brealey, R. A. and Myers S. C. (1991) 'Principles of corporate finance', McGraw Hill, US, (4th edition).

48 Ittner, C. D. (1999) Activity-based costing concepts for quality improve- ment', European Management Journal, Vol. 17, No. 5, pp. 88-99.

49 The probability distribution could be normal (bell-shaped curve); level; triangular; or skewed.

50 Amram, M. and Kulatilaka, N. (1999) 'Real options', Harvard Business School Press, Boston, US.

51 Buckley, A. and Tse, K. (1996) 'Real operating options and foreign direct investment: A synthetic approach', European Management Journal, Vol. 14, No. 3, pp. 304-314.

52 Flatto, J. (1998) 'Using real options in project evaluation', Resource - The Magazine for Life Insurance.

53 Luehrman, T. A. (1998) 'Investment opportunities as real options: Getting started on the numbers', Harvard Business Review, pp. 51-67.

54 Lebas, M. (1999) 'Which ABC? Accounting based on causality rather than activity-based costing', European Management Journal, Vol. 17, No. 5.

55 EIU (1998) op. cit.

56 Schultz, D. E. and Bailey, S. (2000) 'Developing a total customer marketing programme', Journal of Targeting, Measurement and Analysis for Marketing, Vol. 8, No. 4, pp. 303-313. 